\title{
Aplikasi Pupuk Urea, Pupuk Hayati Penambat Nitrogen Dan Amelioran Untuk Meningkatkan pH, C-Organik, Populasi Bakteri Penambat Nitrogen dan Hasil Jagung pada Inceptisols
}

${ }^{1}$ Mieke Rochimi Setiawati, ${ }^{2}$ Yudith Silfani, ${ }^{1}$ Nadia Nuraniya Kamaluddin dan ${ }^{1}$ Tualar Simarmata

${ }^{1}$ Staff Pengajar Program Studi Agroteknologi Fakultas Pertanian Universitas Padjadjaran

${ }^{2}$ Mahasiswi Program Studi Agroteknologi Fakultas Pertanian Universitas Padjadjaran

Jl. Raya Bandung Sumedang Km 21, Jatinangor

Korespondensi: miekesetiawati@yahoo.com;

\begin{abstract}
Inceptisols is known as one of the less-fertile dryland soil order that is widely used for corn cultivation. Proper type and dose of fertilizer can overcome the plant nutrition deficiency and increase corn yield in Inceptisols. This research aimed to examine whether the application of Urea with different doses, $N$-fixing biofertilizer and ameliorant can affect $\mathrm{pH}$, Organic $\mathrm{C}, \mathrm{N}$-fixing bacteria population, and corn yield. The research was conducted at Balai Pengembangan Benih Hortikultura dan Aneka Tanaman Pasir Banteng, Jatinangor from January to June 2020. This research used Randomized Block Design with 16 treatments. The result showed that application of Urea with different doses, $N$-fixing biofertilizer and ameliorant significantly affected $N$-fixing bacteria population and corncob weight. $40 \%$ dose of Urea and 2 ton ha-1 ameliorant gave the best increase in corncob weight per plant of Bisi-2 by $345 \mathrm{~g}$.
\end{abstract}

Keywords: maize, Inceptisols, dose of Urea, Nitrogen-fixing bacteria, ameliorant.

\section{PENDAHULUAN}

Kebutuhan jagung hibrida untuk pakan ternak dan bahan baku industri diperkirakan terus meningkat melebihi kebutuhan jagung untuk rumah tangga. Peningkatan kebutuhan jagung hibrida dapat terus terpenuhi melalui peningkatan luas panen dan produktivitas jagung (Pusat Data dan Sistem Informasi Pertanian, 2018). Berdasarkan Badan Litbang Pertanian (2007) dalam Suastika (2018) 79\% areal pertanaman jagung terdapat di lahan kering dan sisanya berturut-turut 10-15\% sawah irigasi dan 20-30\% sawah tadah hujan.

Inceptisols termasuk salah satu ordo lahan kering dengan kesuburan relatif rendah yang banyak digunakan untuk membudidaya-kan tanaman jagung. Di Indonesia tanah Inceptisol menempati $37,5 \%$ dari total daratan atau seluas 70,52 juta hektar (Puslittanak, 2006 dalam Yuniarti dkk., 2019). Tanah Inceptisols memiliki kandungan bahan organik rendah, $\mathrm{pH}$ yang masam, kapasitas tukar kation (KTK) rendah sampai tinggi, serta kejenuhan basa (KB) rendah sampai tinggi (Sudirja, 2007; Damanik dkk., 2011).

Rendahnya kandungan bahan organik, $\mathrm{pH}$, KTK, dan KB pada tanah Inceptisols dapat dipengaruhi oleh asal pembentukan tanah, pengolahan tanah dan erosi. Tanah Inceptisols terbentuk sebagai hasil dari pencucian dan erosi yang aktif (Soil Survey Staff, 1999). Proses pencucian dan erosi yang terjadi dapat mengakibatkan tercucinya anion dan kation basa yang berperan penting dalam pemenuhan kebutuhan hara tanaman.

Pemanfaatan lahan kering masam untuk penanaman atau budi daya tanaman secara intensif perlu dimulai dengan rehabilitasi lahan dengan memanfaatkan pembenah tanah (amelioran) agar lahan dapat dimanfaatkan dengan optimal (Nurida dkk., 2013). Amelioran merupakan bahan-bahan alami yang dimasukkan ke dalam tanah yang berfungsi memperbaiki sifat fisik (agregasi, infiltrasi dan permeabilitas tanah), kimia (KTK dan unsur hara) dan biologi tanah (meningkatkan C-organik yang merupakan sumber nutrisi biota tanah) (Subatra, 2013). Selain itu, pemupukan juga menjadi salah satu upaya untuk mengoptimalkan produktivitas jagung dalam rangka mengimbangi permintaan kebutuhan jagung (Rajiman, 2016).

Penggunaan kapur sebagai amelioran masih dinilai paling efektif untuk mengatasi kemasaman tanah (Balai Penelitian Tanah, 2012). Kapur dolomit atau yang memiliki 
rumus kimia $\mathrm{CaCO}_{3} \mathrm{MgCO}_{3}$ merupakan bahan yang baik untuk ameliorasi lahan masam. Kandungan ion $\mathrm{Ca}^{2+}$ dan $\mathrm{Mg}^{2+}$ dalam dolomit dapat menggantikan kedudukan ion $\mathrm{Al}^{3+}$ penyebab kemasaman tanah lalu membentuk ikatan dengan $\mathrm{HCO}_{3}$ sehingga $\mathrm{pH}$ tanah naik (Shaaban dkk., 2015). Penggunaan kompos kotoran ayam dapat meningkatkan $\mathrm{pH}, \mathrm{C}$ organik, unsur hara N, P, K dan KTK (Tufaila dkk., 2014; Surya dan Suyono, 2013).

Biochar merupakan bahan padatan hasil konversi termokimia dari biomasa pada kondisi oksigen yang terbatas (IBI, 2015). Aplikasi biochar pada lahan pertanian dapat meningkatkan kemampuan menahan air dan hara, memperbaiki kegemburan tanah, mengurangi penguapan, menekan perkembangan hama dan penyakit serta menciptakan habitat yang baik untuk mikroorganisme (Balittanah, 2015). Asam humat memiliki kemampuan untuk mengadsorbsi berbagai jenis logam melalui gugus karboksil dan fenolik dengan membentuk senyawa kompleks yang sukar larut serta turut menyumbang unsur $\mathrm{N}$, C-organik, dan KTK tanah (Ihdaryanti, 2011). Hasil penelitian Misra dkk. (2019), menunjukkan pupuk Guano yang berasal dari kotoran kelelawar memiliki kandungan hara makro dan mikro utama yang cukup lengkap yaitu P, K, S, Ca, Mg, Na, dll.

Nitrogen merupakan unsur hara makro paling utama yang dibutuhkan tanaman. Namun, pupuk Urea bersifat memasamkan tanah dan unsur hara tanaman cenderung tidak tersedia pada kondisi masam. Pupuk hayati penambat $\mathrm{N}$ diketahui mampu mengurangi penggunaan pupuk $\mathrm{N}$ anorganik melalui mekanisme penambatan $\mathrm{N}$ dari udara. Bakteri penambat $\mathrm{N}$ non simbiotik lebih luas penggunaannya. Dua genus bakteri penambat $\mathrm{N}$ non simbiotik diantaranya Azotobacter dan Azospirillum. Selain itu, bakteri endofit penambat $\mathrm{N}$ juga banyak ditemukan dan dapat hidup di dalam jaringan tanaman tanpa menyebabkan penyakit serta memiliki potensi untuk menambat $\mathrm{N}$ (Muangthong dkk., 2015; Zain dkk., 2018).

Beberapa penelitian sebelumnya telah membuktikan aplikasi kombinasi pupuk Urea dengan amelioran maupun pupuk hayati penambat $\mathrm{N}$ dapat menghasilkan pertumbuhan vegetatif dan generatif tanaman jagung yang lebih baik. Aplikasi kombinasi pupuk Urea, pupuk hayati dan amelioran dengan dosis yang tepat diharapkan dapat mengoptimalkan pertumbuhan tanaman jagung.

\section{BAHAN DAN METODE}

Percobaan dimulai dengan pembuatan pupuk hayati penambat $\mathrm{N}$ pada media carrier. Komposisi carrier terdiri dari kompos kotoran ayam, gambut, biochar tempurung kelapa dan aditif ( $\mathrm{Zn}$ dan $\mathrm{Cu}$ ). Isolat bakteri penambat $\mathrm{N}$ yang digunakan yaitu: Azotobacter chroococcum, Azospirillum sp., dan bakteri Endofit (strain En3) koleksi Laboratorium Biologi Tanah Departemen Ilmu Tanah dan Sumber Daya Lahan, Universitas Padjadjaran.

Masing-masing isolat disuspensikan dengan $\mathrm{NaCl}$ fisiologis $(0,85 \% \mathrm{NaCl})$ ke dalam media starter cair James Nitrogen Free Bromothimol Blue (JNFB). Setelah diinkubasi selama 5 hari, dilakukan penghitungan kepadatan populasi masing-maisng isolat dari media starter dengan metode Total Plate Count (TPC). Masing-masing isolat dari media starter kemudian diinjeksikan ke dalam carrier sebanyak 10 $\%$ dari carrier (3,33\% setiap isolat). Sebelum diaplikasikan, terlebih dahulu dihitung kepadatan populasi bakteri penambat N (BPN) pada carrier dengan metode TPC. Dilakukan juga analisis kimia dan biologi tanah awal dan analisis amelioran terlebih dahulu sebelum pelaksanaan percobaan.

Pupuk Urea sesuai dosis perlakuan, $1200 \mathrm{~g}$ ha $^{-1}$ pupuk hayati penambat $\mathrm{N}$ dan 2 ton ha-1 amelioran diaplikasikan pada pertanaman jagung di tanah Inceptisols, Pasir Banteng, Jatinangor. Pupuk SP-36 dosis $200 \mathrm{~kg} \mathrm{ha}^{-1}$ dan $\mathrm{KCl} 200 \mathrm{~kg} \mathrm{ha}^{-1}$ juga diberikan sebagai pupuk dasar. Pupuk Urea dan $\mathrm{KCl}$ diberikan $50 \%$ pada 1 MST dan $50 \%$ pada 3 MST pada lubang tugalan disamping lubang tanam. Pupuk SP-36 diberikan $100 \%$ pada saat tanam dengan cara ditugal di samping lubang tanam. Amelioran yang digunakan merupakan gabungan dari kompos kotoran ayam, biochar, dolomit, asam humat dan guano. Pupuk hayati dan amelioran diberikan pada saat tanam pada lubang tanam. Pupuk hayati padat yang akan diaplikasikan 
terlebih dahulu diencerkan dengan amelioran dengan perbandingan pupuk hayati dan amelioran 1:100.

Analisis $\mathrm{pH}, \mathrm{C}$-organik dan populasi BPN dilakukan pada fase vegetatif akhir (8 MST) dengan mencabut tanaman dan mengambil sampel tanah pada daerah rizosfer. Komponen hasil yang meliputi bobot tongkol berkelobot dan bobot pipilan per petak diamati pada saat panen (103 hari). Pengujian signifikansi pada taraf 5\% dan uji lanjut Duncan's Multiple Range Test (DMRT) dilakukan dengan menggunakan software SPSS.

\section{HASIL DAN PEMBAHASAN}

\subsection{Kepadatan Populasi Pupuk Hayati Penambat $\mathbf{N}$ dan Analisis Tanah Awal}

Pupuk hayati penambat $\mathrm{N}$ memiliki kepadatan populasi 9,01 x $10^{8} \mathrm{CFU} \mathrm{g}^{-1}$. Kepadatan populasi tersebut telah memenuhi syarat kepa- datan populasi minimal pupuk hayati majemuk yaitu $\geq 10^{7}$ (Permentan, 2019) sehingga dapat digunakan untuk perlakuan di lapangan.

Lahan percobaan sebelum perlakuan memiliki $\mathrm{pH}_{2} \mathrm{O}$ agak masam $(5,95)$, kadar Corganik sedang $(2,30 \%)$, $\mathrm{N}$-total sedang $(0,21 \%)$, rasio $\mathrm{C} / \mathrm{N}$ sedang (11), KTK sedang $\left(23,61 \mathrm{cmol} \mathrm{kg}^{-1}\right)$ dan $\mathrm{KB}$ rendah $(27,7 \%)$. Tekstur tanah adalah lempung liat berdebu. Amelioran yang digunakan memiliki kadar Corganik sebesar 13,27\% dan C/N rasio 22,52.

\section{$3.2 \mathrm{pH}$ Tanah Inceptisol}

Pemberian pupuk Urea berbagai dosis, pupuk hayati penambat $\mathrm{N}$ dan amelioran tidak memberikan pengaruh nyata terhadap $\mathrm{pH}$ tanah Ineptisols. Namun demikian, nilai ratarata $\mathrm{pH}$ pada semua perlakuan lebih tinggi dibandingkan nilai $\mathrm{pH}$ tanah awal sebelum perlakuan (Tabel 1).

Tabel 1 Nilai Rata-Rata Kemasaman Tanah Inceptisol Pasir Banteng Setelah Perlakuan Pupuk Urea Berbagai Dosis, Pupuk Hayati dan Amelioran

\begin{tabular}{|c|c|c|}
\hline Simbol & Perlakuan & pH \\
\hline $\mathrm{N}_{1}$ & $100 \%$ dosis Urea & 6,56 \\
\hline $\mathrm{N}_{2}$ & $100 \%$ dosis Urea $+1200 \mathrm{~g} \mathrm{ha}^{-1}$ pupuk hayati penambat $\mathrm{N}$ & 6,61 \\
\hline $\mathrm{N}_{3}$ & $100 \%$ dosis Urea +2 ton $\mathrm{ha}^{-1}$ amelioran & 7,40 \\
\hline $\mathrm{N}_{4}$ & $100 \%$ dosis Urea $+1200 \mathrm{~g} \mathrm{ha}^{-1}$ pupuk hayati penambat $\mathrm{N}+2$ ton ha-1 amelioran & 7,64 \\
\hline $\mathrm{N}_{5}$ & $80 \%$ dosis Urea & 6,47 \\
\hline $\mathrm{N}_{6}$ & $80 \%$ dosis Urea $+1200 \mathrm{~g} \mathrm{ha}^{-1}$ pupuk hayati penambat $\mathrm{N}$ & 6,69 \\
\hline $\mathrm{N}_{7}$ & $80 \%$ dosis Urea +2 ton ha $^{-1}$ amelioran & 6,85 \\
\hline $\mathrm{N}_{8}$ & $80 \%$ dosis Urea $+1200 \mathrm{~g} \mathrm{ha}^{-1}$ pupuk hayati penambat $\mathrm{N}+2$ ton ha-1 amelioran & 7,00 \\
\hline $\mathrm{N}_{9}$ & $60 \%$ dosis Urea & 6,68 \\
\hline $\mathrm{N}_{10}$ & $60 \%$ dosis Urea $+1200 \mathrm{~g} \mathrm{ha}^{-1}$ pupuk hayati penambat $\mathrm{N}$ & 6,92 \\
\hline $\mathrm{N}_{11}$ & $60 \%$ dosis Urea +2 ton ha-1 amelioran & 6,92 \\
\hline $\mathrm{N}_{12}$ & $60 \%$ dosis Urea $+1200 \mathrm{~g} \mathrm{ha}^{-1}$ pupuk hayati penambat $\mathrm{N}+2$ ton ha-1 amelioran & 7,55 \\
\hline $\mathrm{N}_{13}$ & $40 \%$ dosis Urea & 6,94 \\
\hline $\mathrm{N}_{14}$ & $40 \%$ dosis Urea $+1200 \mathrm{~g} \mathrm{ha}^{-1}$ pupuk hayati penambat $\mathrm{N}$ & 7,03 \\
\hline $\mathrm{N}_{15}$ & $40 \%$ dosis Urea +2 ton ha $^{-1}$ amelioran & 7,29 \\
\hline $\mathrm{N}_{16}$ & $40 \%$ dosis Urea $+1200 \mathrm{~g} \mathrm{ha}^{-1}$ pupuk hayati penambat $\mathrm{N}+2$ ton ha-1 amelioran & 7,45 \\
\hline
\end{tabular}

Menururt Widyati (2013), proses penyerapan nitrogen dalam bentuk nitrat oleh akar tanaman menghasilkan senyawa hidroksil yang membuat rizosfer menjadi semakin alkalis. Amonium dari hasil hidrolisis Urea dapat mengalami perubahan menjadi nitrit oleh bakteri Nitrosomonas, Nitrosococcus dan Nitrosopira lalu menjadi nitrat oleh bakteri Nitrobacter (Thakur dan Medhi, 2019).
Selain pengaruh penyerapan hara oleh tanaman jagung, kenaikan $\mathrm{pH}$ juga dipengaruhi oleh bahan-bahan yang terdapat dalam amelioran. Proses humifikasi kompos kotoran ayam akan menghasilkan asam humat dan asam fulvat (Wahyudi, 2009). Selain itu, terdapat juga asam humat sebagai salah satu komposisi dalam amelioran. Asam humat diketahui dapat berikatan kuat dengan $\mathrm{Al}^{3+}$ pada permukaan 
mineral liat, dimana $\mathrm{Al}^{3+}$ merupakan penyebab kemasaman tanah (Boguta dan Sokolowska, 2013). Kandungan Ca dan Mg pada dolomit dapat menggantikan kedudukan ion penyebab kemasaman pada kompleks jerapan sehingga dapat meningkatkan $\mathrm{pH}$.

Pengaruh perlakuan yang tidak nyata terhadap $\mathrm{pH}$ disebabkan karena cukup banyak faktor yang dapat mempengaruhi nilai $\mathrm{pH}$ tanah Selain kenaikan $\mathrm{pH}$, terdapat juga proses-proses yang dapat menurunkan $\mathrm{pH}$ tanah diantaranya pupuk yang bereaksi masam serta respirasi akar dan mikroorganisme. Pupuk Urea diketahui merupakan pupuk yang bereaksi masam dalam tanah yang dibuktikan dengan penelitian Damanik dkk. (2014) bahwa pemberian Urea pada Inceptisols cenderung meningkatkan $\mathrm{pH}$ pada minggu ke-3 hingga ke6 setelah aplikasi. Hasil respirasi mikroba maupun akar tanaman berupa $\mathrm{CO}_{2}$ dapat menurunkan $\mathrm{pH}$ melalui pembetukkan asam karbonat dan bikarbonat jika berikatan dengan air (Widyati, 2013).

Masing-masing komponen yang terkandung dalam amelioran dan proses yang terjadi di daerah perakaran (rizosfer) ada yang berpotensi meningkatkan dan menurunkan $\mathrm{pH}$ sehingga aplikasi perlakuan menjadi tidak berbeda nyata.

\subsection{Kadar C-Organik}

Pemberian pupuk Urea berbagai dosis, pupuk hayati penambat $\mathrm{N}$ dan amelioran tidak memberikan pengaruh nyata terhadap Corganik. Kadar C-organik tanah pada seluruh perlakuan lebih rendah dibandingkan kadar Corganik tanah awal sebelum perlakuan yaitu 2,30\% (Tabel 2). Sampel yang digunakan untuk analisis C-organik adalah tanah pada bagian perakaran tanaman jagung Bisi-2, maka kadar C-organik juga turut dipengaruhi prosesproses yang terjadi pada lingkungan rizosfer.

Tabel 2 Kadar C-Organik Rata-Rata Tanah Inceptisols Pasir Banteng Setelah Perlakuan Pupuk Urea berbagai dosis, Pupuk Hayati dan Amelioran

\begin{tabular}{|c|c|c|}
\hline Simbol & Perlakuan & C-organik (\%) \\
\hline $\mathrm{N}_{1}$ & $100 \%$ dosis Urea & 1,05 \\
\hline $\mathrm{N}_{2}$ & $100 \%$ dosis Urea $+1200 \mathrm{~g} \mathrm{ha}^{-1}$ pupuk hayati penambat $\mathrm{N}$ & 1,31 \\
\hline $\mathrm{N}_{3}$ & $100 \%$ dosis Urea+2 ton ha-1 amelioran & 1,44 \\
\hline $\mathrm{N}_{4}$ & $\begin{aligned} 100 \% \text { dosis Urea }+1200 \mathrm{~g} \mathrm{ha}^{-1} \text { pupuk hayati penambat } \mathrm{N} \\
+2 \text { ton } \mathrm{ha}^{-1} \text { amelioran }\end{aligned}$ & 1,15 \\
\hline $\mathrm{N}_{5}$ & $80 \%$ dosis Urea & 1,11 \\
\hline $\mathrm{N}_{6}$ & $80 \%$ dosis Urea $+1200 \mathrm{~g} \mathrm{ha}^{-1}$ pupuk hayati penambat $\mathrm{N}$ & 1,11 \\
\hline $\mathrm{N}_{7}$ & $80 \%$ dosis Urea +2 ton ha $^{-1}$ amelioran & 1,22 \\
\hline $\mathrm{N}_{8}$ & $\begin{array}{l}80 \% \text { dosis Urea }+1200 \mathrm{~g} \mathrm{ha}^{-1} \text { pupuk hayati penambat } \mathrm{N} \\
+2 \text { ton } \mathrm{ha}^{-1} \text { amelioran }\end{array}$ & 1,18 \\
\hline $\mathrm{N}_{9}$ & $60 \%$ dosis Urea & 1,07 \\
\hline $\mathrm{N}_{10}$ & $60 \%$ dosis Urea $+1200 \mathrm{~g} \mathrm{ha}^{-1}$ pupuk hayati penambat $\mathrm{N}$ & 1,03 \\
\hline $\mathrm{N}_{11}$ & $60 \%$ dosis Urea +2 ton $\mathrm{ha}^{-1}$ amelioran & 1,25 \\
\hline $\mathrm{N}_{12}$ & $\begin{aligned} 60 \% \text { dosis Urea }+1200 \mathrm{~g} \mathrm{ha}^{-1} \text { pupuk hayati penambat } \mathrm{N} \\
+2 \text { ton ha-1 amelioran }\end{aligned}$ & 1,46 \\
\hline $\mathrm{N}_{13}$ & $40 \%$ dosis Urea & 1,48 \\
\hline $\mathrm{N}_{14}$ & $40 \%$ dosis Urea $+1200 \mathrm{~g} \mathrm{ha}^{-1}$ pupuk hayati penambat $\mathrm{N}$ & 1,06 \\
\hline $\mathrm{N}_{15}$ & $40 \%$ dosis Urea +2 ton ha-1 amelioran & 0,96 \\
\hline $\mathrm{N}_{16}$ & $\begin{array}{l}\begin{array}{r}40 \% \text { dosis Urea }+1200 \mathrm{~g} \mathrm{ha}^{-1} \text { pupuk hayati penambat } \mathrm{N} \\
+2 \text { ton } \mathrm{ha}^{-1} \text { amelioran }\end{array} \\
\end{array}$ & 1,21 \\
\hline
\end{tabular}

Keterangan: Perlakuan pupuk Urea berbagai dosis, pupuk hayati dan amelioran tidak berpengaruh nyata terhadap kadar C-organik tanah Inceptisols pada taraf nyata 5\%

Menurut Raka dkk. (2012), akar tanaman jagung mengeluarkan senyawa asam amino triptopan, asam glucuronic, dan karbohidrat. Asam amino dan karbohidrat diduga berperan sebagai chemoattractancs bagi Plant Growth Promoting Rhizobacteria (PGPR). Berdasarkan Nguema-Ona dkk. (2013), arabinogalactan proteins (AGPs) yang termasuk dalam kelom- 
pok glikoprotein dinding sel tanaman memegang peranan dalam interaksi akar dan mikroba rizosfer. Senyawa AGPs diketahui sebagai senyawa esensial bagi pertumbuhan bakteri rizosfer pada tanaman legum maupun non legum (Xie dkk., 2012).

Senyawa yang dihasilkan dari akar tanaman membuat aktivitas mikroorganisme pada daerah rizosfer menjadi lebih tinggi sehingga penyerapan karbon menjadi lebih tinggi. Karbon diperlukan mikroba sebanyak $88 \%$ untuk pertumbuhan dan $12 \%$ untuk menghasilkan energi (Spohn dkk., 2016). Pupuk hayati penambat $\mathrm{N}$ yang diaplikasikan sebagai perlakuan juga menambah konsumsi C-organik dari dalam tanah.

\subsection{Populasi Bakteri Penambat N (BPN)}

Pemberian pupuk Urea berbagai dosis, pupuk hayati dan amelioran berpengaruh nyata terhadap kepadatan populasi bakteri penambat N (BPN) tanah Inceptisol. Perlakuan Urea dosis $60 \%$ (180 kg ha-1), $1200 \mathrm{~g} \mathrm{ha}^{-1}$ pupuk hayati penambat $\mathrm{N}$ dan 2 ton ha ${ }^{-1}$ amelioran $\left(\mathrm{N}_{12}\right)$ nyata menghasilkan jumlah populasi BPN yaitu 53,4 x $10^{8} \mathrm{CFU} \mathrm{g}^{-1}$ (Tabel 3).

Tabel 3 Pengaruh Pupuk Urea Berbagai Dosis, Pupuk Hayati dan Amelioran terhadap Populasi BPN pada Tanah Inceptisols Pasir Banteng

\begin{tabular}{|c|c|c|}
\hline Simbol & Perlakuan & $\begin{array}{l}\text { Populasi BPN } \\
\left(\ldots \times 10^{8} \mathrm{CFU} \mathrm{g}^{-1}\right)\end{array}$ \\
\hline $\mathrm{N}_{1}$ & $100 \%$ dosis Urea & $18,9 \mathrm{ab}$ \\
\hline $\mathrm{N}_{2}$ & $100 \%$ dosis Urea $+1200 \mathrm{~g} \mathrm{ha}^{-1}$ pupuk hayati penambat $\mathrm{N}$ & $35,9 \mathrm{bc}$ \\
\hline $\mathrm{N}_{3}$ & $100 \%$ dosis Urea +2 ton ha $^{-1}$ amelioran & $2,50 \mathrm{a}$ \\
\hline $\mathrm{N}_{4}$ & 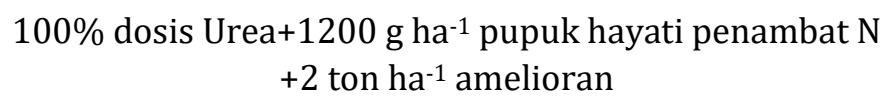 & $24,7 \mathrm{abc}$ \\
\hline $\mathrm{N}_{5}$ & $80 \%$ dosis Urea & $16,8 \mathrm{ab}$ \\
\hline $\mathrm{N}_{6}$ & $80 \%$ dosis Urea $+1200 \mathrm{~g} \mathrm{ha}^{-1}$ pupuk hayati penambat $\mathrm{N}$ & $1,60 \mathrm{a}$ \\
\hline $\mathrm{N}_{7}$ & $80 \%$ dosis Urea +2 ton ha $^{-1}$ amelioran & $2,00 \mathrm{a}$ \\
\hline $\mathrm{N}_{8}$ & $\begin{array}{c}80 \% \text { dosis Urea }+1200 \mathrm{~g} \mathrm{ha}^{-1} \text { pupuk hayati penambat } \mathrm{N} \\
+2 \text { ton ha-1 amelioran }\end{array}$ & $9,07 \mathrm{ab}$ \\
\hline $\mathrm{N}_{9}$ & $60 \%$ dosis Urea & $2,13 \mathrm{a}$ \\
\hline $\mathrm{N}_{10}$ & $60 \%$ dosis Urea $+1200 \mathrm{~g} \mathrm{ha}^{-1}$ pupuk hayati penambat $\mathrm{N}$ & $8,73 \mathrm{ab}$ \\
\hline $\mathrm{N}_{11}$ & $60 \%$ dosis Urea +2 ton ha $^{-1}$ amelioran & $31,3 \mathrm{abc}$ \\
\hline $\mathrm{N}_{12}$ & $\begin{array}{l}60 \% \text { dosis Urea }+1200 \mathrm{~g} \mathrm{ha}^{-1} \text { pupuk hayati penambat } \mathrm{N} \\
+2 \text { ton ha-1 amelioran }\end{array}$ & $53,4 \mathrm{c}$ \\
\hline $\mathrm{N}_{13}$ & $40 \%$ dosis Urea & $14,3 \mathrm{ab}$ \\
\hline $\mathrm{N}_{14}$ & $40 \%$ dosis Urea $+1200 \mathrm{~g} \mathrm{ha}^{-1}$ pupuk hayati penambat $\mathrm{N}$ & $11,5 \mathrm{ab}$ \\
\hline $\mathrm{N}_{15}$ & $40 \%$ dosis Urea +2 ton $\mathrm{ha}^{-1}$ amelioran & $12,7 \mathrm{ab}$ \\
\hline $\mathrm{N}_{16}$ & $\begin{array}{l}40 \% \text { dosis Urea }+1200 \mathrm{~g} \mathrm{ha}^{-1} \text { pupuk hayati penambat } \mathrm{N} \\
+2 \text { ton ha } \mathrm{h}^{-1} \text { amelioran }\end{array}$ & $4,40 \mathrm{ab}$ \\
\hline
\end{tabular}

Keterangan: Angka yang diikuti huruf notasi yang sama tidak berbeda nyata menurut uji jarak berganda Duncan (DMRT) pada taraf nyata 5\%.

Menurut Volk dan Wheeler (1988), mikroba membutuhkan nutrien dalam bentuk karbon, nitrogen, ion anorganik, metabolit penting (vitamin, asam amino), dan air. Pada perlakuan $\mathrm{N}_{12}$ diduga merupakan kondisi yang paling mendukung untuk pertumbuhan BPN dimana semua sumber yang dibutuhkan untuk pertumbuhan bakteri terpenuhi dengan baik. Selain itu, biochar yang terdapat dalam amelioran juga disebut menjadi tempat yang baik untuk pertumbuhan mikroba karena bersifat porous (Sarwono, 2016).

Pertumbuhan mikroorganisme membutuhkan 2 unsur penting yaitu karbon (C) sebagai sumber energi dan nitrogen $(\mathrm{N})$ sebagai penyusun sel. Nisbah $\mathrm{C} / \mathrm{N}$ yang paling baik antara 30-40 yaitu mikroorganisme mendapatkan cukup energi dan nitrogen. Nisbah $\mathrm{C} / \mathrm{N}$ 
yang tinggi menyebabkan terhambatnya aktivitas mikroorganisme akibat kekurangan protein pembentuk sel. Sedangkan nisbah C/N yang rendah menyebabkan akumulasi gas amonia sehingga $\mathrm{N}$ mudah hilang ke udara. Diduga pada perlakuan $\mathrm{N}_{12}$ seluruh unsur yang dibutuhkan untuk pertumbuhan bakteri terpenuhi dengan baik dan memiliki nisbah $\mathrm{C} / \mathrm{N}$ yang paling sesuai untuk pertumbuhan dan aktivitas mikroorganisme.

\subsection{Bobot Tongkol Berkelobot}

Pemberian pupuk Urea berbagai dosis, pupuk hayati dan amelioran memberikan pengaruh nyata terhadap bobot tongkol berkelobot jagung Bisi-2. Perlakuan Urea dosis $40 \%$ (120 kg ha-1) dan 2 ton ha-1 amelioran $\left(\mathrm{N}_{15}\right)$ menghasilkan rata-rata bobot tongkol berkelobot jagung Bisi-2 yaitu 345,34 g yang berbeda nyata dengan perlakuan pemberian Urea dosis $100 \%$ dengan atau tanpa pupuk hayati dan amelioran $\left(\mathrm{N}_{1}, \mathrm{~N}_{2}, \mathrm{~N}_{3}, \mathrm{~N}_{4}\right)$ (Tabel 4). Hal ini menunjukkan bahwa peningkatan dosis Urea tidak selalu meningkatkan bobot tongkol berkelobot jagung Bisi-2. Hal ini sejalan dengan Suratmini (2009) bahwa pemupukan Urea pada lahan kering dengan dosis $150 \mathrm{~kg} \mathrm{ha}^{-1}$ berbeda nyata meningkatkan bobot tongkol segar dibandingkan kontrol (tanpa pupuk Urea) tetapi tidak berbeda nyata pada pemberian Urea dosis 300 dan $450 \mathrm{~kg} \mathrm{ha}^{-1}$.

Pembesaran tongkol jagung Bisi-2 dipengaruhi oleh unsur nitrogen yang diberikan melalui pupuk Urea dan penambatan oleh bakteri penambat N. Menurut Rasyid dkk. (2010), pada tanaman jagung unsur $\mathrm{N}$ berperan dalam memperbesar tongkol dan meningkatkan kandungan protein. Menurut Wibowo dkk. (2017), peningkatan bobot tongkol berkelobot berkaitan erat dengan fotosintat yang ditranslokasikan ke tongkol jagung. Dengan demikian proses fotosintesis tanaman jagung Bisi-2 pada perlakuan $\mathrm{N}_{15}$ berlangsung dengan efektif sehingga fotosintat yang diarahkan pada pembentukan tongkol menjadi optimal.

Tabel 4 Pengaruh Pupuk Urea Berbagai Dosis, Pupuk Hayati dan Amelioran terhadap Bobot Tongkol Kelobot Jagung Bisi-2 pada Tanah Inceptisols Pasir Banteng

\begin{tabular}{|c|c|c|}
\hline Simbol & Perlakuan & $\begin{array}{c}\text { Bobot Tongkol Kelobot } \\
\text { Rata-Rata per Tanaman }(\mathrm{g})\end{array}$ \\
\hline $\mathrm{N}_{1}$ & $100 \%$ dosis Urea & $284,34 \mathrm{abc}$ \\
\hline $\mathrm{N}_{2}$ & $100 \%$ dosis Urea $+1200 \mathrm{~g} \mathrm{ha}^{-1}$ pupuk hayati penambat $\mathrm{N}$ & 291,86 abcd \\
\hline $\mathrm{N}_{3}$ & $100 \%$ dosis Urea +2 ton ha $^{-1}$ amelioran & $262,99 \mathrm{a}$ \\
\hline $\mathrm{N}_{4}$ & $\begin{array}{c}\begin{aligned} 100 \% \text { dosis Urea } & +1200 \mathrm{~g} \mathrm{ha}^{-1} \text { pupuk hayati penambat } \mathrm{N} \\
& +2 \text { ton } \mathrm{ha}^{-1} \text { amelioran }\end{aligned}\end{array}$ & $297,10 \mathrm{abcd}$ \\
\hline $\mathrm{N}_{5}$ & $80 \%$ dosis Urea & 302,06 abcde \\
\hline $\mathrm{N}_{6}$ & $80 \%$ dosis Urea $+1200 \mathrm{~g} \mathrm{ha}^{-1}$ pupuk hayati penambat $\mathrm{N}$ & 307,9 abcde \\
\hline $\mathrm{N}_{7}$ & $80 \%$ dosis Urea +2 ton ha-1 amelioran & 319,91 bcde \\
\hline $\mathrm{N}_{8}$ & $\begin{array}{c}80 \% \text { dosis Urea }+1200 \mathrm{~g} \mathrm{ha}^{-1} \text { pupuk hayati penambat } \mathrm{N} \\
+2 \text { ton ha-1 }^{-1} \text { amelioran }\end{array}$ & $284,44 \mathrm{abc}$ \\
\hline $\mathrm{N}_{9}$ & $60 \%$ dosis Urea & 326,16 cde \\
\hline $\mathrm{N}_{10}$ & $60 \%$ dosis Urea $+1200 \mathrm{~g} \mathrm{ha}^{-1}$ pupuk hayati penambat $\mathrm{N}$ & $276,97 \mathrm{ab}$ \\
\hline $\mathrm{N}_{11}$ & $60 \%$ dosis Urea +2 ton ha $^{-1}$ amelioran & $266,58 \mathrm{a}$ \\
\hline $\mathrm{N}_{12}$ & $\begin{array}{c}60 \% \text { dosis Urea }+1200 \mathrm{~g} \mathrm{ha}^{-1} \text { pupuk hayati penambat } \mathrm{N} \\
+2 \text { ton ha-1 amelioran }\end{array}$ & $317,84 \mathrm{bcd}$ \\
\hline $\mathrm{N}_{13}$ & $40 \%$ dosis Urea & $285,05 \mathrm{abc}$ \\
\hline $\mathrm{N}_{14}$ & $40 \%$ dosis Urea $+1200 \mathrm{~g} \mathrm{ha}^{-1}$ pupuk hayati penambat $\mathrm{N}$ & 305,75 abcde \\
\hline $\mathrm{N}_{15}$ & $40 \%$ dosis Urea +2 ton ha-1 amelioran & $345,34 \mathrm{e}$ \\
\hline $\mathrm{N}_{16}$ & $\begin{array}{c}40 \% \text { dosis Urea }+1200 \mathrm{~g} \mathrm{ha}^{-1} \text { pupuk hayati penambat } \mathrm{N} \\
+2 \text { ton ha-1 amelioran }\end{array}$ & 333,15 de \\
\hline
\end{tabular}

Keterangan: Angka yang diikuti huruf notasi yang sama tidak berbeda nyata menurut uji jarak berganda Duncan (DMRT) pada taraf nyata 5\%. 


\subsection{Bobot Pipilan per Petak}

Hasil analisis menunjukkan tidak terdapat pengaruh yang nyata terhadap bobot pipilan per petak dari pemberian Urea berbagai dosis, pupuk hayati penambat $\mathrm{N}$ dan amelioran (Tabel 5). Hal ini diduga karena bobot pipilan jagung pada percobaan ini lebih dipengaruhi oleh faktor genetik benih BISI-2. Menurut Yati dan Permadi (2015), bobot pipilan kering jagung hibrida dipengaruhi oleh beberapa faktor diantaranya kerapatan tanaman, jumlah tongkol per tanaman, jumlah baris per tongkol, jumlah biji per baris, dan bobot 1000 butir. Benih Bisi-2 merupakan benih hibrida yang memiliki 2 tongkol per tanaman, jumlah baris per tongkol 12-14 baris dan rata-rata hasil pipilan kering 8,9 ton ha-1. Jumlah tongkol per tanaman dan jumlah baris per tongkol yang tetap (dipengaruhi faktor genetik) akan mempengaruhi jumlah pipilan per tanaman dan berpengaruh juga terhadap jumlah pipilan per petak.

Tabel 5 Bobot Pipilan per Petak Jagung Bisi-2 Setelah Perlakuan Pupuk Urea Berbagai Dosis, Pupuk Hayati dan Amelioran

\begin{tabular}{|c|c|c|}
\hline Simbol & Perlakuan & $\begin{array}{l}\text { Bobot Pipilan } \\
\text { per Petak }(g)\end{array}$ \\
\hline $\mathrm{N}_{1}$ & $100 \%$ dosis Urea & 2088,0 \\
\hline $\mathrm{N}_{2}$ & $100 \%$ dosis Urea $+1200 \mathrm{~g} \mathrm{ha}^{-1}$ pupuk hayati penambat $\mathrm{N}$ & 2405,0 \\
\hline $\mathrm{N}_{3}$ & $100 \%$ dosis Urea +2 ton $\mathrm{ha}^{-1}$ amelioran & 2235,3 \\
\hline $\mathrm{N}_{4}$ & $\begin{array}{c}100 \% \text { dosis Urea }+1200 \mathrm{~g} \mathrm{ha}^{-1} \text { pupuk hayati penambat } \mathrm{N} \\
+2 \text { ton } \mathrm{ha}^{-1} \text { amelioran }\end{array}$ & 2107,7 \\
\hline $\mathrm{N}_{5}$ & $80 \%$ dosis Urea & 2006,0 \\
\hline $\mathrm{N}_{6}$ & $80 \%$ dosis Urea $+1200 \mathrm{~g} \mathrm{ha}^{-1}$ pupuk hayati penambat $\mathrm{N}$ & 1743,7 \\
\hline $\mathrm{N}_{7}$ & $80 \%$ dosis Urea +2 ton ha $^{-1}$ amelioran & 1630,0 \\
\hline $\mathrm{N}_{8}$ & $\begin{array}{l}80 \% \text { dosis Urea }+1200 \mathrm{~g} \mathrm{ha}^{-1} \text { pupuk hayati penambat } \mathrm{N} \\
+2 \text { ton ha-1 amelioran }\end{array}$ & 2420,3 \\
\hline $\mathrm{N}_{9}$ & $60 \%$ dosis Urea & 2031,3 \\
\hline $\mathrm{N}_{10}$ & $60 \%$ dosis Urea $+1200 \mathrm{~g} \mathrm{ha}^{-1}$ pupuk hayati penambat $\mathrm{N}$ & 1885,3 \\
\hline $\mathrm{N}_{11}$ & $60 \%$ dosis Urea +2 ton ha $^{-1}$ amelioran & 2325,0 \\
\hline $\mathrm{N}_{12}$ & $\begin{aligned} 60 \% \text { dosis Urea } & +1200 \mathrm{~g} \mathrm{ha}^{-1} \text { pupuk hayati penambat } \mathrm{N} \\
& +2 \text { ton } \mathrm{ha}^{-1} \text { amelioran }\end{aligned}$ & 2178,0 \\
\hline $\mathrm{N}_{13}$ & $40 \%$ dosis Urea & 2100,3 \\
\hline $\mathrm{N}_{14}$ & $40 \%$ dosis Urea $+1200 \mathrm{~g} \mathrm{ha}^{-1}$ pupuk hayati penambat $\mathrm{N}$ & 2133,0 \\
\hline $\mathrm{N}_{15}$ & $40 \%$ dosis Urea +2 ton ha ${ }^{-1}$ amelioran & 2378,3 \\
\hline $\mathrm{N}_{16}$ & $\begin{array}{l}40 \% \text { dosis Urea }+1200 \mathrm{~g} \mathrm{ha}^{-1} \text { pupuk hayati penambat } \mathrm{N} \\
+2 \text { ton ha-1 amelioran }\end{array}$ & 2795,3 \\
\hline
\end{tabular}

Hasil pipilan jagung Bisi-2 pada seluruh perlakuan masih berada di bawah rata-rata hasil pipilan jagung Bisi-2 yaitu 8,9 ton ha-1 ${ }^{-1}$ Hal ini diduga terjadi karena pengaruh dari $\mathrm{pH}$ tanah, frekuensi pemupukan dan penyerapan hara nitrogen jagung Bisi-2. Dugaan tersebut muncul karena kondisi-kondisi lainnya yang meliputi temperatur, kelembaban nisbi, curah hujan dan intensitas penyinaran pada saat pelaksanaan percobaan telah memenuhi syarat tumbuh tanaman jagung. Tanaman berbiji (termasuk jagung) membutuhkan pasokan $\mathrm{N}$ yang relatif tinggi selama pengisian biji
(Sinclair dan de Wit, 1975 dalam Wangiyana dkk., 2010). Pemberian Urea pada fase pengisian biji dapat meningkatkan jumlah daun hijau yang aktif menghasilkan fotosintat sehingga dapat meningkatkan bobot biji (Wangiyana dkk., 2010).

Pada saat percobaan, pupuk Urea diberikan dengan frekuensi sebanyak 2 kali selama masa tanam yaitu pada 1 MST dan 3 MST. Sedangkan fase pengisian biji dimulai saat memasuki 8 MST, sehingga fotosintat yang dibutuhkan saat fase ini diambil dari daun dan ditranslokasikan ke biji. Disamping itu, aplikasi 
pupuk hayati penambat $\mathrm{N}$ hanya dilakukan pada saat penanaman sehingga kemungkinan bakteri Azotobacter chroococcum, Azospirillum sp. dan bakteri endofit (En3) telah mengalami fase penurunan populasi sehingga aktivitas penambatan $\mathrm{N}$ berkurang.

\section{KESIMPULAN}

Pemberian pupuk Urea berbagai dosis, pupuk hayati penambat $\mathrm{N}$ dan amelioran memberikan pengaruh nyata dalam meningkatkan populasi BPN dan bobot tongkol berkelobot jagung Bisi-2 tetapi tidak berpengaruh nyata terhadap $\mathrm{pH}, \mathrm{C}$-Organik dan bobot pipilan jagung Bisi-2. Pemberian Urea dosis 40\% (120 kg ha-1) dan 2 ton ha-1 amelioran $\left(\mathrm{N}_{15}\right)$ merupakan perlakuan terbaik untuk menghasilkan bobot tongkol berkelobot jagung Bisi-2 per tanaman yang paling tinggi yaitu $345 \mathrm{~g}$.

\section{UCAPAN TERIMA KASIH}

Ucapan terima kasih disampaikan kepada Rektor Universitas Padjadjaran atas pendanaan yang diberikan melalui Hibah Riset Academic Leadership Grant (ALG) 2020.

\section{DAFTAR PUSTAKA}

Balai Penelitian Tanah. 2012. Laporan Akhir Penelitian Insentif Ristek. Kerjasama Penelitian Badan Litbang Pertanian dan Kemenristek. Badan Litbang Pertanian. Balai Penelitian Tanah. Bogor

Balai Penelitian Tanah. 2015. Biochar: Pembenah Tanah yang Potensial. Badan Penelitian dan Pengembangan Pertanian. Bogor.

Bogota, P. dan Sokolowska, P. 2013. Acta Agrophysica Monographiae: Interactions of Humic Acids with Metal. Bohdan Dobrzański Institue od the Polish Academy of Sciences. Polandia

Damanik, M.M.B., E.H. Bachtiar., Fauzi., Sarifuddin dan H. Hamidah. 2010. Kesuburan Tanah dan Pemupukan. Medan: USU Press.
Damanik, A. R. B., H. Hanum dan Sarifuddin. 2010. Dinamika $\mathrm{N}-\mathrm{NH}_{4}$ dan $\mathrm{N}-\mathrm{NO}_{3}$ akibat pemberian pupuk urea dan kapur $\mathrm{CaCO}_{3}$ pada tanah Inceptisol Kwala Bekala dan kaitannya terhadap pertumbuhan tanaman jagung. Jurnal Online Agroekoteknologi. 2(3): 1218-1227.

Ihdaryanti M. A. 2011. Pengaruh Asam Humat dan Cara Pemberiannya terhadap Pertumbuhan dan Produktivitas Tanaman Padi (Oryza sativa) [Skripsi]. Bogor: Institut Pertanian Bogor.

International Biochar Initiative. 2015. Standardized Product Definition and Product Testing Guidlines for Biochar That is Used in Soil. International Biochar Initiative. United States.

Misra, P.K., N. K. Gautam, V. Elangovan. 2019. Bat guano: a rich source of macro and microelements essential for plant growth. Annals of Plants and Soil Research. 21(1): 82-86.

Muangthong, A., S. Youpensuk, dan B. Rerkasem. 2015. Isolation and characterisation of endophytic nitrogen fixing bacteria in sugarcane. Tropical Life Science Research. 26(1): 41-51.

Muyassir, Sufardi, dan Saputra, I. 2012. Perubahan sifat fisika Inceptisol akibat perbedaan jenis dan dosis pupuk organik. Lentera. 12 (1):1-8.

Nguema-Ona, E., M. Vicre-Gibouin, M-A, Cannesan, dan A. Driouich. 2013. Arabinogalactan proteins in rootmicrobe interactions. Trends Plant Sci. 18(8): 440-449.

Nurida N. L., Dariah A. dan Sutono. 2014. Ameliorasi lahan kering masam mendukung produktivitas kedelai pada Ultisol Sukadana Lampung Timur. Dalam: Prosiding Seminar Nasional Hasil Penelitian Tanaman Aneka Kacang dan Umbi. Malang, 5 Juni 2014. Hal: $294-304$.

Peraturan Menteri Pertanian Republik Indonesia No.01/2019 tentang Pendaftaran Pupuk Organik, Pupuk 
Hayati, dan Pembenah Tanah. Kementerian Pertanian. Jakarta.

Pusat Data dan Sistem Informasi Pertanian. 2018. Outlook Komoditas Pertanian Subsektor Tanaman Pangan Jagung. Kementerian Pertanian. Jakarta. http://epublikasi.setjen.pertanian.o.i d/arsip-outlook/81-outlooktanaman-pangan/637-outlookjagung-2018

Rajiman. 2017. Pengaruh takaran pupuk hayati dan dosis pupuk anorganik terhadap hasil jagung. Prosiding Seminar Nasional Fakultas Pertanian UNS 1(1)

Raka, I. G. N., K. Khalimi, I. D. N. Nyana dan I. K. Siadi. 2012. Aplikasi rizobakteri Pantoea agglomerans untuk meningkatkan pertumbuhan dan hasil tanaman jagung (Zea mays, L.) varietas hibrida BISI-2. Agrotrop. 2(1): 1-9.

Rasyid, B., Samosir, S. S. R. dan Sutomo, F. 2010. Respon tanaman jagung (Zea mays) pada berbagai regim air tanah dan pemberian pupuk nitrogen. Dalam: Prosiding Pekan Serealia Nasional. Maros, 26-30 Juli 2010. Hal:26-34.

Sarwono, R. 2016. Biochar sebagai penyimpan karbon, perbaikan sifat tanah, dan mencegah pemanasan global: tinjauan. Jurnal Kimia Terapan Indonesia. 18(1):79-90.

Shaaban, M., Q. Peng, R. Hu, Y. Wu, S. Lin, J. Zhao. 2015. Dolomite application to acidic soils: a promising option for mitigating $\mathrm{N}_{2} \mathrm{O}$ emission. Environtmental Science and Pollution Research. 22: 1996119970.

Soil Survey Staff. 1999. Soil Taxonomy: A Basic of Soil Classification for Making and Interpreting Soil Surveys, Second Edition. Natural Resources Conservation Service USDA. United States.

Spohn, M., E. M. Potsch, S. A. Eichorst, D. Woebken, W. Wanek, dan A. Ritcher. 2016. Soil microbial carbon use efficiency and biomass turnover in a long-term fertilization experiment in a temperate grassland. Soil Biology \& Biochemistry. 97: 168-175.

Suastika, I. W. 2018. Sistem pengelolaan lahan tadah hujan mendukung pengembangan kawasan pangan dan hortikultura. [Proposal Penelitian] Bogor: Balai Penelitian Tanah.

Subatra, K. 2013. Pengaruh sisa amelioran, pupuk Urea dan $P$ terhadap ketersediaan $\mathrm{N}$, pertumbuhan dan hasil tanaman padi di musim tanam kedua pada tanah gambut. Jurnal Lahan Suboptimal. 2(2):159-169.

Sudirja, R., M. A. Solihin, dan S. Rosniawaty. 2007. Respons beberapa sifat kimia Inceptisol asal Rajamandala dan hasil bibit kakao melalui pemberian pupuk organik dan pupuk hayati [Laporan Penelitian]. Bandung: Universitas Padjadjaran.

Suratmini, P. 2009. Kombinasi pemupukan Urea dan pupuk organik pada jagung manis di lahan kering. Jurnal Tanaman Pangan. 28(2): 83-88.

Surya, R. E. dan Suyono. 2013. Pengaruh pengomposan terhadap rasio $\mathrm{C} / \mathrm{N}$ kotoran ayam dan kadar hara NPK tersedia serta kapasitas tukar kation tanah. UNESA Journal of Chemistry 2(1): 137-144.

Thakur, I. S. dan Medhi, K. 2019. Nitrification and denitrification processes for mitigation of nitrous oxide from waste water treatment plants for biovalorization: challenges and opportunities. Bioresource Technology. 282: 502-513.

Volk, W. A. dan Wheeler, M. F. 1988. Mikrobiologi Dasar Edisi Kelima Jilid I. Jakarta: Erlangga.

Wahyudi, I. 2009. Serapan N tanaman jagung (Zea mays L.) akibat pemberian pupuk guano dan pupuk hijau lamtoro pada Ultisol Wanga. Jurnal Agroland. 16(4): 265-272.

Wangiyana, W., M. H. Anan dan I. K. Ngawit. 2010. Peningakatan hasil jagung hibrida var. Bisi-2 dengan aplikasi pupuk kandang sapi dan peningkatan frekuensi pemberian Urea dan 
campuran SP-36 dan KCl. CROP AGRO, Jurnal Ilmiah Budidaya 3(1):55-56.

Wibowo, A. S., N. Barunawati. dan M. D. Maghfour. 2017. Respons hasil tanaman jagung manis (Zea Mays L. Saccharata) terhadap pemberian $\mathrm{KCl}$ dan pupuk kotoran ayam. Jurnal Produksi Tanaman. 5(8): 1386-1387.

Widyati, E. 2013. Memahami interaksi tanaman-mikroba (Understanding on Plants-Microbes Interactions). Tekno Hutan Tanaman. 6(1):13 - 20.

Xie, F., Williams, A., A. Edwards dan J. A. Downie. 2012. A plant arabinogalactanlike glycoprotein promotes a novel type of polar surface attachment by Rhizobium leguminosarum. Mol. Plant-Microbe Interact. 25(2): 250-258.

Yati, H., dan Permadi, K. 2015. Implementasi pengelolaan tanaman terpadu pada jagung hibrida (Zea mays L.). Agrotrop. 5(1): 101-109.

Yuniarti, A., M. Damayani dan D. M. Nur. 2019. Efek pupuk organik dan pupuk N, P, K terhadap C-organik, N-total, C/N, serapan serta hasil padi hitam pada Inceptisols. Jurnal Pertanian Presisi. 3(2):91-94.

Zain, N. M., Bachtiar, T. dan Sugoro, I. 2018. Kontribusi nitrogen dari bakteri endofit pada tanaman padi. Jurnal Ilmiah Aplikasi Isotop dan Radiasi. 14(1): 6-8. 